\title{
Board 47: Year 2 of an S-STEM Summer Scholarship for a Sophomore Bridge Program
}

\section{Dr. Katie Evans, Louisiana Tech University}

Dr. Katie Evans is the Associate Dean of Strategic Initiatives, the Entergy Corp LP\&L/NOPSI \#3 \& \#4 Professor of Mathematics, the Academic Director of Mathematics and Statistics and Online programs, and the Director of the Integrated STEM Education Research Center (ISERC). She earned her Ph.D. in Mathematics and M.S. in Mathematics at Virginia Tech, Blacksburg, VA. Her research interests include distributed parameter control modeling and simulation, dynamic modeling of physical systems, and STEM education. She has published 20 peer-reviewed publications in these areas, and her research has been funded by the NSF, AFRL, and LA-BOR.

\section{Dr. Mitzi Desselles, Louisiana Tech University}

Dr. Desselles is Associate Professor and holds the Chester Ellis Endowed Professorship in the Department of Psychology and Behavioral Sciences at Louisiana Tech University. She is a member of the graduate faculty in Industrial/Organizational Psychology.

\section{Dr. Marisa K. Orr, Clemson University}

Marisa K. Orr is an Assistant Professor in Engineering and Science Education with a joint appointment in the Department of Mechanical Engineering at Clemson University. Her research interests include student persistence and pathways in engineering, gender equity, diversity, and academic policy. Dr. Orr is a recipient of the NSF CAREER Award for her research entitled, "Empowering Students to be Adaptive Decision-Makers." 


\section{Year 2 of an S-STEM Summer Scholarship for a Sophomore Bridge Program}

In Summer 2017, Louisiana Tech University launched an S-STEM Scholarship Program to serve as a Sophomore Bridge Program for engineering majors. The program was specifically designed to provide engineering majors with a smoother transition into the more difficult mathematics and engineering coursework that typically accompanies the sophomore year. The scholarship program takes places over a 12-week summer term in which participants enroll in the first multivariable calculus course, statics, and a two-credit hour professional development course (ENGR 189B). Program feedback from the eighteen scholarship recipients of Summer 2017 led to significant changes in the professional development course for Summer 2018, which included seventeen scholarship recipients. This paper will describe the modifications made to the ENGR 189B professional development course to address student feedback. Feedback from Summer 2018 participants revealed that these changes were positively received. For reference, this paper also provides a brief background on the criteria for students to participate in the program.

\section{Background on Scholarship Selection}

The design of this scholarship program requires that students enroll in specific courses during the summer after their first year in engineering. Therefore, the most significant scholarship criterion is that students be on-track in the mathematics, engineering, and science courses required in their curricula at end of their first year spring term. Therefore, as long as students pass their mathematics, engineering, and science courses, they will be ready for the summer courses required by the scholarship program at the end of their first academic year. These on-track students would normally enroll in the courses funded by the S-STEM scholarship during the Fall term of their sophomore year. The scholarship affords the students the opportunity to take the classes one term early during the summer 1$)$ over a longer period of time (12-week summer term vs. 10-week academic year term) and 2) while the students are not taking as many other courses (9-12 vs. 8 credit hours).

\section{ENGR 189B Course Redesign}

The 2017 professional development course included four components: 1) curricular content from Studying Engineering: A Road Map to a Rewarding Career [1], 2) the entire curriculum from Developing Spatial Thinking [2], 3) visits to area companies utilizing engineering methods in the workplace, and 4) faculty mentorship through faculty participation in the industry visits. Feedback from the program participants indicated requests for 1) increased career development activities, e.g. resume building, 2) re-working of the Developing Spatial Thinking content, and 3) industry trips to be made relevant to life as a future engineer. The grant team reflected on the student feedback with respect to the existing course elements and program structure and agreed that improvements could be made. Table 1 provides a summary of the changes implemented in the ENGR 189B course for the Summer 2018 Program, including the addition of course threads that were not present during the Summer 2017 Program. Student reactions to the revised ENGR 189B professional development course were obtained through the annual evaluation survey, and their reception to the revised content was very positive. 
Table 1. ENGR 189B Professional Development Course Changes from Year 1 to Year 2

\begin{tabular}{|c|c|c|c|c|}
\hline $\begin{array}{l}\text { Course } \\
\text { Thread }\end{array}$ & $\begin{array}{c}2017 \\
\text { Implementation }\end{array}$ & $\begin{array}{l}2017 \text { Student } \\
\text { Feedback }\end{array}$ & 2018 Implementation & 2018 Student Feedback \\
\hline Industry trips & $\begin{array}{l}\text { Visited regional } \\
\text { companies, most but } \\
\text { not all employed } \\
\text { engineers. }\end{array}$ & $\begin{array}{l}\text { Industry trips should be } \\
\text { more relevant to life as } \\
\text { a future engineer. } \\
\text { Visits to } 2 \text { companies } \\
\text { not seen as beneficial. }\end{array}$ & $\begin{array}{l}\text { Retained highly engineering-focused } \\
\text { industry trips from } 2017 \text { and replaced } \\
\text { visits that had been less engineering } \\
\text { focused. Assigned students to research } \\
\text { companies prior to the visit. }\end{array}$ & $\begin{array}{l}\text { All industry trips rated } \\
\text { favorably. }\end{array}$ \\
\hline $\begin{array}{l}\text { Spatial } \\
\text { Visualization }\end{array}$ & $\begin{array}{l}\text { Taught entire } \\
\text { Developing Spatial } \\
\text { Thinking curriculum }\end{array}$ & $\begin{array}{l}\text { Some students not } \\
\text { interested and found it } \\
\text { to be a waste of time, } \\
\text { while others found } \\
\text { material challenging }\end{array}$ & $\begin{array}{l}\text { Taught entire Developing Spatial } \\
\text { Thinking curriculum }\end{array}$ & No student comments. \\
\hline $\begin{array}{l}\text { Studying } \\
\text { Engineering }\end{array}$ & $\begin{array}{l}\text { A few elements of } \\
\text { Studying Engineering } \\
\text { implemented. }\end{array}$ & $\begin{array}{l}\text { Students requested } \\
\text { additional career } \\
\text { development content. }\end{array}$ & $\begin{array}{l}\text { N/A: Content discontinued and replaced } \\
\text { with other career development content. }\end{array}$ & N/A \\
\hline $\begin{array}{l}\text { Professional } \\
\text { communication }\end{array}$ & N/A & N/A & $\begin{array}{l}\text { Students drafted thank you notes as a } \\
\text { class to send to companies after visits. }\end{array}$ & No student comments. \\
\hline $\begin{array}{l}\text { Personal } \\
\text { strengths }\end{array}$ & N/A & N/A & $\begin{array}{l}\text { Students took CliftonStrengths } \\
\text { assessment. Assignments and in-class } \\
\text { activities focused on using their } \\
\text { strengths to guide their résumé } \\
\text { development and interview strategies. }\end{array}$ & No student comments. \\
\hline $\begin{array}{l}\text { Résumé } \\
\text { building }\end{array}$ & N/A & N/A & $\begin{array}{l}\text { Students drafted and revised résumés } \\
\text { repeatedly in response to grant team } \\
\text { feedback. Résumé "speed dating," } \\
\text { where students rate de-identified } \\
\text { résumés of classmates. }\end{array}$ & $\begin{array}{l}\text { Want more résumé } \\
\text { assistance. Résumé “speed } \\
\text { dating" highly rated as one } \\
\text { of the students' favorite } \\
\text { activities. }\end{array}$ \\
\hline $\begin{array}{l}\text { Interviewing } \\
\text { skills }\end{array}$ & N/A & N/A & Interview skills and practice workshop & $\begin{array}{l}\text { Want more interview } \\
\text { practice. }\end{array}$ \\
\hline Team building & N/A & N/A & $\begin{array}{l}\text { Implemented "Marble Run" team } \\
\text { communication activity. }\end{array}$ & $\begin{array}{l}\text { Highly rated as one of the } \\
\text { students' favorite activities. }\end{array}$ \\
\hline
\end{tabular}


Overall, the students were more satisfied with several new or revised elements of the program. They were more positive about the engineering-focused industry visits. They appreciated the new interview and résumé-building activities and especially enjoyed the team-building exercise. They had little to say, however, about the CliftonStrengths ${ }^{\circledR}[3]$ assessment on which the new résumé and interview activities were designed to build. One area in which students requested more assistance was on résumé development. The team made a choice not to provide example résumés before the first draft was due so that there would be a wide variety of résumé styles for the first review activity where students quickly rated blinded peer résumés and discussed what stood out to them. The team expected that they might want more assistance, but did not expect the first draft to be as much of a struggle as it turned out to be.

The team kept the entire Developing Spatial Thinking curriculum despite some complaints by the 2017 cohort, because some students were able to improve their skills as a result of the instruction. The 2018 cohort did not report any problems. This might be due to a change of the instructor. Another possible explanation is that the greater variety of content in the 2018 ENGR 189B Course (spatial visualization and professional development) may have been more interesting to students and created a more engaging overall experience.

\section{Conclusions and Future Work}

Student feedback after year 1 provided effective criteria for selecting and arranging industry visits. Selecting sites and speakers that could give relevant information about life as an engineer resulted in greater satisfaction and relevance for the students, therefore we will continue to seek these types of trips.

Student feedback suggests that the résumé-building activities and interviewing workshops were beneficial but could be revised to provide more feedback and practice for students. These activities will be re-evaluated to determine an appropriate level of scaffolding, especially for the first draft résumé. The team will also refine the evaluations to probe more deeply into student reactions to the CliftonStrengths assessment, in order to determine whether the lack of comment should be interpreted as negative, positive, or neutral.

The team will continue with the Developing Spatial Thinking curriculum and seek ways to enhance its relevance and raise the level of student engagement with the material, such as integrating with the Computer-Aided Modeling software that students learned in their first year. The team is also exploring potential curricular content using 3-D holographic, augmented reality technology that connects with students' mobile devices (MERGE Cube®) [4]. The system allows students to hold a virtual object in their hands and experiment with manipulating the holographic images via smartphone. 


\section{References}

[1] R. B. Landis, Studying Engineering: A Road Map to a Rewarding Career, 4th ed., Anaheim, CA: Discovery Press, 2013.

[2] S. A. Sorby, Developing Spatial Thinking, Boston, MA: Delmar Cengage Learning, 2011.

[3] M. C. Louis, The Clifton StrengthsFinder and Student Strengths Development, Omaha NE: The Gallup Organization, 2012.

[4] https://mergevr.com/educators

\section{Acknowledgments}

This material is supported by NSF DUE \#1564768. Any opinions, findings, conclusions, and recommendations expressed are those of the authors and do not necessarily reflect the views of the National Science Foundation. 